УДК [37+930.85]:94[(431)(092)+(44)(092)]

DOI https://doi.org/10.32838/2663-5984/2021/1.17

\title{
Гордієнко В.В.
}

Уманський державний педагогічний університет імені Павла Тичини

\section{Гордіснко Г.М.}

Уманський державний педагогічний університет імені Павла Тичини

\section{МІСЦЕ ОСВІТИ Й КУЛЬТУРИ В ДІЯННЯХ ФРІДРІХА ІІ ГОГЕНШТАУФЕНА ТА ЛЮДОВИКА ІХ СВЯТОГО}

У статті здійснено компаративний аналіз важливого аспекту реформаторської діяльності видатних монархів Високого Середньовіччя Західної Свропи імператора Священної Римської імперї Фрідріха II Гогенштауфена і короля Франщії Людовика IX Святого. Охарактеризовано причини зачікавленості імператора і короля питаннями розвитку літератури, мистецтва, освіти і науки. Висвітлено мотиви тісного спілкування монархів із видатними інтелектуалами епохи Високого Середньовіччя. Виявлено особливості контактів і взаємодіі Фрідріха II і Людовика IX з поетами, митиями і богословами.

У статті аналізується ставлення державиів до поетичної творчості трубадурів, труверів, міннезингерів. Вказано на значний вплив на розвиток європейської літератури «Сииилійської школи поетів», яка виникла під егідою імператора Фрідріха II. Зазначено, що імператор утримував при своєму дворі не тільки поетів і митців, а й відомих на той час мислителів і вчених. Наголошено на тому, що франиузький король Людовик IX не захоплювався рицарською поезією, хоча й не забороняв ї̈ у своєму королівстві. Його приваблювали малі жанри иерковного мистеитва: проповідь, иерковна музика, книжскова мініатюра. На відміну від Фрідріха II, Людовик IX більше спілкувався і співпрачював з інтелектуалами середнього рівня Робером Сорбоном і Вінцентом із Бове.

Розкрито зміст уявлень монархів про феномен середньовічного університету і його місію. Підкреслено, щчо Фрідріх II порушив монополію папства на заснування університетів $і$ відкрив перший у Середні віки світський вищий навчальний заклад у Неаполі. Людовик IX хоча й не мав відношення до заснування Паризького університету, але зробив усе залежне від нього, щоб магістри і студенти університету повернулися до Парижа після страйку 1229-1231 рр. Обтрунтовано висновок про те, щзо діяльність Людовика ІХ як опікуна і благодійника без втручання у внутрішнє життя Паризького університету виявилася в перспективі більш плідною, ніж утилітарно-прагматичний підхід Фрідріха II до університету в Неаполі.

Ключові слова: Фрідріх II, Людовик IX, Неаполітанський університет, Паризький університет, інтелектуали, освіта.

Постановка проблеми. Серед видатних європейських правителів Високого Середньовіччя імператор Священної Римської імперії Фрідріх II Гогенштауфен i французький король Людовик IX Святий займають особливе місце. Обидва монархи залишили глибокий слід в історії Європи і світу. Багатогранна діяльність німецького імператора і короля Франції віддавна викликала жвавий інтерес науковців із різних галузей гуманітаристики.

Відомо, що ці державці з великою повагою ставилися один до одного. Кожен із них по-своєму виконував свою монаршу місію, намагаючись утвердити свою державу як провідну в Західній Європі. Обидва правителі були хрестоносцями й особисто очолили три походи на Святу Землю для того, щоб відвоювати у мусульман Гроб Господній. Імператор і король Франції прославилися своїми реформами в галузі державного управління й судочинства. Вони були успішними дипломатами, захисниками християнської віри і рицарями, опікувалися освітою і наукою, розуміючи їхнє значення для успішної держави. Але імператор i король по-різному турбувалися про функціонування вищої школи у своїх володіннях, у кожного 3 них склалися особливі стосунки 3 видатними інтелектуалами епохи.

Аналіз останніх досліджень і публікацій. Про монархів писали видатні історики XX ст. Е. Канторович [10], Ж.Ле Гофф [11], Е. Віс [4], Б. Глогер [2], М. Абрамсон [1]. Мимоволі, досліджуючи біографії цих історичних персон, нау- 
ковці вдавалися до порівнянь. Ще середньовічні хроністи встановили кардинальну відмінність між Фрідріхом і Людовиком як видатними особистостями. Звісно, насамперед істориків цікавив досвід монархів як політиків, які доклали чимало власних зусиль для зміцнення своїх держав й утвердження династій.

Для історика зрозумілою є теза: масштаб державця в історичній перспективі значною мірою визначається й тим, якими були його стосунки 3 інтелектуалами епохи і яким було його ставлення до передових знань і освіти. Вивчаючи діяння імператора й короля, науковці не залишали поза увагою питання про місце культури та освіти в біографії цих таких несхожих один на одного і водночас близьких монархів. Проте, висвітлюючи ці аспекти, історики ще не застосовували акцентовано компаративний метод для розв'язання вказаних дослідницьких завдань.

Постановка завдання. Для кращого осмислення місця й ролі в європейській історії Фрідріха II і Людовика IX варто порівняти їхню діяльність у галузі культури та освіти. Науковий інтерес становить специфіка взаємодії монархів із відомими інтелектуалами епохи і провідними університетами імперії та королівства. Необхідно порівняти й результати активності державців щодо підтримки вищої школи - унікального феномену соціокультурного життя середньовічної Європи.

Виклад основного матеріалу дослідження. У своїй багатогранній діяльності, спрямованій на удосконалення системи управління і суспільних відносин, і німецький імператор, і французький король спиралися на знання й досвід фахових юристів, богословів, медиків. Не отримавши в юності системної освіти, Фрідріх II і Людовик IX на все життя зберегли жагу до знань і повагу до освічених людей. Завдяки цьому вони змогли реалізувати унікальні реформи у своїх володіннях.

Уже сучасники захоплювалися реформаторською діяльністю монархів. Для втілення у життя масштабних заходів щодо поліпшення системи управління, функціонування державного апарату і судочинства правителі потребували досвідчених і знаючих фахівців - юстиціаріїв, суддів, прокурорів, нотаріусів, легістів, секретарів. Звідси їхній особливий інтерес до питань освіти й функціонування вищих шкіл у своїх володіннях, які готували освічених кліриків і чиновників-професіоналів.

Фрідріх II і Людовик IX для надання особливого блиску своїм дворам запрошували й утримували біля себе видатних інтелектуалів епохи. Німецький історик Й. Шер так писав про Гогенш- тауфена: «Образ Фрідріха II оточений особливим блиском. Він стояв далеко вище від забобонів i обмеженості свого часу, він був вищою мірою сприйнятливим до прекрасного в житті й мистецтві, сильно прив'язаний до більш вільного світоспоглядання, закоханий у світлу і яскраву природу півдня, сміливий мислитель, в усіх відношеннях приваблива особистість, приваблива навіть у своїх слабостях, велика в нещасті» [15, с. 140].

Імператорський двір у Палермо в роки правління Фрідріха II став осередком дивовижного літературного феномену - «Сицилійської школи поетів». У їі надрах зародилася італійська поезія народною мовою (вольгаре). Відомо, що вірші на сицилійському діалекті італійської мови писав як сам Фрідріх, так і його сини - Енцо і Манфред. Сицилійську школу в середньовічній Європі прославили своєю творчістю талановиті інтелектуали й поети Райнально да Аквіно, Кобо да Морра, Фолько Руффо та інші. Світова література завдячує Джакомо да Лентіні - імперському нотаріусові і членові Сицилійської школи за появу витонченої поетичної форми - сонету [1, с. 288].

Утверджуючи свою владу на німецьких землях протягом 1212-1220 рр., молодий Фрідріх не забував і про літературу. Він наблизив до себе видатного німецького міннезингера Вальтера фон дер Фогельвейде. Щоб відчути хоча б частково особливу духовну атмосферу двору імператора Фрідріха II Гогентштауфена, варто звернути увагу на невеличкий фрагмент російськомовного перекладу елегії Вальтера фон дер Фогельвейде:

«Увы, промчались годы, сгорели все дотла!

Иль жизнь мне только снилась! Иль впрямь она была!

О молодые люди, увы, прошла пора,

Когда, любивший радость, растил вас дух Двора» [3, с. 152].

Імператор пожалував видатному міннезингерові, який, незважаючи на свій талант і популярність у можновладців, жив у бідності, ленний маєток [9, с. 829]. У свиті імператора виділявся своїми талантами трубадур Пейре Раймон ло Про. Поет супроводжував монарха у знаменитому й успішному Шостому Хрестовому поході [7, с. 282]. Як стверджував Е. Канторович, в епоху Ренесансу правителі-гуманісти дарували видатним поетам, живописцям і скульпторам державні посади. У Фрідріха II був інший підхід: не наділяти особу, яка випадково стала поетом, державними повноваженнями. За його правління частіше освічені чиновники ставали поетами і митцями, а не навпаки [10, с. 329]. 
За словами О.С. Воскобойнікова, гостинність двору монарха для інтелектуалів та поетів була зумовлена унікальною як для середньовічного правителя «допитливістю» Фрідріха II, а також його високим «інтелектуальним горизонтом»на тлі малоосвічених і обмежених королів і князів Західної Свропи [5, с. 257-258]. Ще в Середні віки існувала легенда, що при дворі Фрідріха II тривалий час жив сам Аверроес [10, с. 338]. Насправді ж імператор наблизив до себе видатного науковця (математика, астронома, астролога) Майкла Скотта і часто спілкувався з ним.

Про здобутки мусульманської науки i богослов'я імператор міг дізнатися від каді Сираха ад-діна аль-Урмаві, посла султана Єгипту, який прославився своїми глибокими знаннями з геометрії, астрономії, юриспруденції та теології. Відомо, що свій трактат із логіки мусульманський учений присвятив Фрідріхові II. Iз філософією видатного єврейського мислителя Маймоніда монарха ознайомив Мойсей бен Соломон Салернський. В оточенні імператора були єврейські вчені та перекладачі, зокрема Яков Анатолі. Можна стверджувати, що Фрідріх II цілком збагнув велику значущість інтелектуалів для репрезентації влади ідеального монарха.

Нестандартність мислення і дій як державця Фрідріх II виявив у справі заснування університету. Указ про відкриття вищої школи в Неаполі він підписав у липні 1234 року у Сіракузах. Нестандартність виявилася у тому, що до цього указу питання заснування університетів перебувало винятково у віданні папської курії. Неаполітанський університет - це перша спроба створити світський вищий навчальний заклад. Заснування університету без погодження 3 папською курією міг здійснити монарх, девізом якого було "commodum et utilitas", тобто «вигода і корисність» [4, с. 5].

Указ містив розлоге обгрунтування необхідності такого навчального закладу у володіннях імператора. У тексті указу чітко зазначалося, що університет у Неаполі має готувати фахових чиновників для державного управління в Сицилійському королівстві. Історик М.С. Суворов писав: «Імператор мотивує заснування університету в Неаполі бажанням позбавити своїх підданих необхідності мандрувати, бідувати та голодувати по чужих країнах у пошуках наукової освіти і виставляє на вид, що місто Неаполь поєднує у собі всі умови, що забезпечують приємне і спокійне життя» [14, с. 49-50].

Указом імператора на всій території Сицилійського королівства професорам заборонялося викладати, а студентам слухати лекції, крім новоствореного Неаполітанського університету та вищої медичної школи в Салерно. В указі йшлося про те, що студенти із Сицилійського королівства, які навчалися в європейських університетах, мали залишити свої навчальні заклади, повернутися на батьківщину і вступити до університету в Неаполі. Як фундатор університету, Фрідріх II особисто сформував професорсько-викладацький склад, встановив розміри платні викладачам і працівникам навчального закладу.

Указом гарантувалася безпека студентам під час проїзду до Неаполя по території всієї Священної Римської імперії. 3 огляду на традиційну ксенофобію і жадібність городян, імператор потурбувався про захист інтересів студентства від зазіхань міських корпорацій. Встановлювався максимум вартості житла, яке неапольські домовласники здавали студентам на період навчання. Для дотримання справедливої ціни на житло створювалися спільні комісії у складі двох авторитетних представників міської громади і двох представників корпорації студентів, які перевіряли укладені угоди найму житла студентами.

Навчання в університеті передбачало користування книгами, які в Середні віки становили велику цінність. Фрідріх II своїм указом запровадив вигідний для студентів порядок позики коштів під заставу книг. Поширеним явищем в університетських містах середньовічної Європи була позика украй збіднілими студентами грошей під заставу власних книг. Імператор наказував видавати книги 3-під застави студентам, щоб вони могли продовжити навчання. Для цього вони мусили у присутності міського нотаріуса і двох свідків виголосити клятву в тому, що вони після завершення навчання не поїдуть із Неаполя до тих пір, поки не повернуть заставлену книгу або не повернуть позичені під неї кошти.

Сіракузький указ Фрідріха II надзвичайно детально регламентував побут університетської корпорації. Тут містилися чіткі настанови про порядок призначення на професорські посади i викладання дисциплін, стипендії студентам, суми коштів на харчування студентів. Так, на харчування одного студента в Неаполітанському університеті із казни Сицилійського королівства виділялося дві унції золота. Суворо регламентувався порядок проживання професорів та студентів і навіть порядок видачі книг студентам з університетської бібліотеки [4, с. 126].

Професори й магістри новоствореного університету перебували на державному утриманні. 
Отримуючи платню з казни Сицилійського королівства, вони мусили не тільки навчати своїх студентів, але й виховувати їх у дусі вірності імператорові. Невидима присутність імператора Фрідріха II мала місце, зокрема, при викладанні такої важливої дисципліни в університеті як канонічне право. Професори канонічного права мусили читати лекції, подаючи матеріал в імператорській інтерпретації, а не в теократичній (папській).

Уже у «Мельфійських конституціях» Фрідріх II вирішив упорядкувати процес надання відповідного звання випускникам Салернської медичної школи. Як зазначав О.С. Воскобойніков, імператор «постановив, що усі лікарі повинні були проходити публічний екзамен на зборах професорів медицини Салернської школи в присутності державних чиновників. Після цього, маючи в руках письмове свідоцтво про складання іспиту, вони зобов'язані були з'явитися до імператора або, за його відсутності, до того, хто його заміняє, для отримання дозволу на практику (licentia medendi). Недотримання цієї статті каралося конфіскацією майна й тюремним ув'язненням» [6, с. 296].

Сіракузьким указом імператор упорядкував присвоєння наукових ступенів у своєму університеті. Після завершення курсу навчання студент зобов'язаний був звернутися до імператора з проханням присвоїти йому ліценціат. Правитель у відповідь на прохання наказував професорам відповідного фаху провести випробування студентові. За умови успішного складання іспиту студент ставав ліценціатом і виголошував присягу вірності імператорові. Цікаво, що після цього ліценціат зобов'язаний був протягом двох років навчати студентів у Неаполі.

Оскільки кількість студентів щороку зростала, а у Фрідріха було безліч державних справ, право присвоювати ліценціат було передано канцлерові Сицилійського королівства. Біограф імператора Е. Віс так оцінював активність державця на освітянській ниві: «Одним із найвеличніших звершень імператора Фрідріха II була ліквідація церковної монополії на освіту із заснуванням університету в Неаполі. У цьому випадку справа була не у вченості, не в гуманістичних ідеалах освіти - як майже в усіх його вчинках, а йшлося про владу» [4, с. 126].

Доля університету в Неаполі залежала від перипетій політичної боротьби між імператором та папською курією і конфліктів Фрідріха II із ломбардськими містами. Після смерті Фрідріха II у 1250 році його наступник Конрад IV наказав перевести університет у Салерно й об'єднати його 3 вищою медичною школою. Але сицилійський король Манфред уже після наглої смерті ще молодого Конрада у 1254 році відновив статус-кво, наказавши повернути університет до Неаполя.

Випускники Неаполітанського університету обіймали посади в розгалуженому бюрократичному апараті Сицилійського королівства, а також були фаховими радниками і помічниками Фрідріха II у проведенні імперської політики. Водночас ще наприкінці XIX ст. історики звернули увагу на специфічну рису новоствореного імператорського університету. Е. Віс писав: «На відміну від свого діда, імператора Фрідріха I Барбаросси, який у листопаді 1158 року видав на Ронкальських полях "Privilegium scholasticum" - закон, який запроваджував академічну свободу в Свропі і по сьогоднішній день $\epsilon$ основою вільного навчання й дослідження, Фрідріх заснував у деспотичній державі деспотичний університет» [4, с. 127]. Для Фрідріха і його наступників Конрада та Манфреда університет був лише складником системи державного управління [14, с. 51].

Французький король Людовик IX порівняно 3 імператором Фрідріхом II був державцем іншого типу. Його тривале правління збігається із культурним піднесенням у Франції. Ж.Ле Гофф писав: «Це великий час зведення готичних соборів 3 їхніми вітражами, час мініатюр нового стилю, схоластичного богослов'я в Паризькому університеті, прозаїчних романів про рицарів Круглого столу, «Високого Писання про Святий Грааль» близько 1240 року (Людовику Святому тоді було 26 років), «Роману про Лиса» $\mathrm{i}$ «Роману про Троянду» [11, с. 432].

Незважаючи на те, що образ ідеального короля в Середні віки неодмінно містив такі елементи як богоугодні діяння, опіка та матеріальна підтримка митців і науковців залишилося мало джерел, які б підтверджували свідому участь Людовика IX у культурному процесі. Монарх більше уваги приділяв богоугодним і благочестивим справам. Так, він любив і всіляко заохочував церковну музику. I це не випадково. У Парижі в готичному соборі Нотр-Дам відразу після зведення зародилася унікальна школа церковного багатоголосого співу. Музичні смаки короля формувалися під впливом цієї школи. Король відвідував усі богослужіння у своїй каплиці, де під час денних і нічних годин звучали багатоголосі піснеспіви. Король і сам любив співати, і заохочував до цього своїх рідних і близьких, але залишався цілком байдужим до світської, народної музики. 
Ж.Ле Гофф підкреслював: «Сент-Шапель надавала довкіллю музичну сакральність, яка працювала на авторитет середньовічного короля. Людовик, як ніякий інший монарх або державець, був оточений цією музичною аурою. Його життя, життя короля і людини, було овіяне музикою музикою, яку він мислив молитвою й оммажем Господу, але і інструментом побудови особистості й акомпанементом, що перетворює королівську функцію» [11, с. 433].

Розквіт готики в архітектурі Франції припадав на часи правління Людовика IX. У XIII ст. з'явилися шедеври готичного мистецтва НотрДам де Парі, собори у Шартрі, Ам’єні, Реймсі. Король фінансував і часто ініціював будівництво готичних храмів у своєму королівстві, але його не можна вважати фундатором архітектурного стилю масштабу абата Сугерія. Проте образ святого короля у тій або іншій формі вплинув на архітектурне мистецтво XIII ст. Для сакральної архітектури, на думку фахівців, у цей період була властива особлива «стримана витонченість», якою славилася фігура знаменитого короля. Образ короля цілком відбивається у стильових особливостях так званої «променистої готики».

На відміну від свого сучасника Фрідріха II, Людовик IX виявляв холодну стриманість до поезії трубадурів і менестрелів. Він міг спокійно із ввічливості споглядати виступ знаменитого поета чи менестреля, якого йому пропонував хтось із аристократів королівства, але захоплення у нього цей вид мистецтва ніколи не викликав [8, с. 157]. Тому джерела не зберегли імен поетів і митців, які б тривалий час перебували у свиті Людовика IX.

Не схожим на імператора Фрідріха II французький король був і у стосунках 3 інтелектуалами. Протягом свого правління він тісно спілкувався лише 3 двома французькими вченими - Робером де Сорбоном і Вінцентом із Бове. Перший був паризьким каноніком, другий - ченцем домініканського ордену. Слід зазначити, що і Робер де Сорбон, і Вінцент із Бове не належали до видатних мислителів і науковців свого часу. Канонік Робер був вихідцем із селян, але, незважаючи на це, зробив успішну церковну кар'єру, сягнувши статусу особистого духовника короля. Він отримав блискучу освіту в Паризькому університеті і прославився своєю проповідницькою діяльністю.

Король був любителем і неабияким знавцем такого жанру церковного мистецтва, як проповідь. Людовик Святий симпатизував Роберові, оскільки той вирізнявся своєю скромністю, схильністю до благочестя і постійною готовністю до покаяння. Але в історію культури Робер де Сорбон насамперед увійшов як фундатор коледжу для бідних магістрів мистецтв, які вивчали теологію в Паризькому університеті. Варто зазначити, що Людовик IX активно підтримав проєкт Робера де Сорбона, передавши для коледжу ділянку землі 3 будівлями в Латинському кварталі Парижа й необхідні кошти. Власне, короля можна вважати співзасновником коледжу, який із часом стане відомим під іменем Сорбонна. Більше того, ця назва пошириться й на весь Паризький університет.

Більше Людовик IX співпрацював із видатним французьким інтелектуалом XIII ст. Вінцентом із Бове. Вінцент розробив і реалізував грандіозний проєкт - укладання енциклопедії "Speculum maius” («Велике дзеркало»). Структуру цього видання складали три розділи: "Speculum naturale" («Дзеркало природи»), "Speculum doctrinale" («Дзеркало науки») i "Speculum historiale” («Дзеркало історії»). Французький король особисто надавав допомогу укладачам унікального видання й навіть подекуди коригував його зміст.

Спілкування короля 3 тодішніми світилами науки й теології мало випадковий характер. Джерела повідомляють, що на одному з обідів у короля був присутній сам Фома Аквінський, а Бонавентура (Джованні Фіданца) на прохання Людовика в королівській каплиці неодноразово виступав зі своїми проповідями. «Діяльність таких відомих у XIII ст. авторитетів, як Фома Аквінський та Альберт Великий, сприяла перетворенню факультету теології Паризького університету в духовний i культурний центр, який користувався заслуженою повагою, де обговорювалися основні питання християнської доктрини», - підкреслює Марі-Анн Поло де Больє у своїй книзі про середньовічну Францію [13, с. 60]. Незважаючи на бурхливе інтелектуальне життя Паризького університету в роки правління Людовика IX, король мало цікавився теологічними і філософськими суперечками, які вирували у стінах закладу. Але коли виникла загроза існуванню навчального закладу, монарх рішуче виступив на його захист.

Середньовічні міські корпорації часто конфліктували між собою. Не уникли цієї долі й університетські об'єднання. Якщо навіть мешканці одного міста подекуди не могли знайти між собою спільної мови, то що вже говорити про ставлення городян із традиційно ксенофобськими настроями до осіб, які прибули до міста на навчання в університет з інших земель. Тексти середньовічних хроністів містять чимало сцен кривавих сутичок між місцевими і студентами університетів. 
1229 рік ознаменувався найбільшим конфліктом між парижанами і студентами. Черговий дебош, який вчинили студенти у корчмі паризького передмістя Сен-Марсель, переріс у непримириме протистояння між університетом і міською владою. Вороже налаштовані до студентів через постійні сутички королівські сержанти і лучники (тодішня поліція) застосували надмірну силу для вгамування молодих хуліганів. Унаслідок цього кілька невинних студентів загинуло. Обурене керівництво університету звернулося до королеви Бланки Кастильської, яка виконувала на той момент обов'язки регента королівства, із проханням відновити справедливість. Не отримавши від влади ніякої відповіді, магістри і студенти університету вирішили назавжди покинути Париж. Їх негайно прийняли у вищі школи Орлеана, Анже, Реймса. Навіть англійський король Генріх III вирішив скористатися ситуацією й запросив до Оксфордського університету магістрів із Парижа.

У цій обстановці юний Людовик IX, якому ще не виповнилося й 16-ти років, ужив рішучих заходів 3 метою повернути вищий навчальний заклад до Парижа. Після тривалих переговорів із представниками університету король звернувся до Папи Римського Григорія IX iз проханням стати посередником у конфлікті парижан 3 університетською корпорацією. Король за власні кошти оплатив судові штрафи за тілесні ушкодження, які отримали студенти під час масової бійки 3 королівськими сержантами у 1229 році. Причетних до вбивств студентів із наказу короля притягнули до суду. Згідно 3 вироком, вони мусили виплатити значну матеріальну компенсацію рідним загиблих. Людовик IX заявив про відновлення привілеїв магістрам і студентам, які вони отримали ще від діда короля - Філіпа II Августа [12, с. 69].

Завдяки активному спілкуванню із французьким королем з приводу ситуації довкола університету папа Григорій IX 13 квітня 1231 року оприлюднив буллу “Parens scientiarum". У культурній історії Західної Європи ця булла стала відомою як «Велика хартія Паризького університету». Текст булли містив чітку настанову: магістри і студенти мають право протестувати і навіть страйкувати у тому випадку, коли влада нехтує їхніми привілеями. Папа істотно обмежив судові повноваження паризького єпископа і його канцлера щодо студентів і професорсько-викладацького складу університету. Буллою суворо заборонялося канцлерові брати під варту студентів. До конфлікту 1229-1231 pр. канцлер мав привілей видавати кандидатам "licentia docenti", тобто, документ, який давав право займатися викладацькою діяльністю. Із джерел можна дізнатися, що канцлер не завжди добросовісно користувався цим привілеєм. Папа Григорій IX у своїй буллі встановив вимогу до канцлера присягати на Євангелії, що він ніколи не присвоїть "licentia docenti" кандидатові без належного іспиту перед відповідною комісією магістрів.

«Велика хартія Паризького університету» містила й настанови щодо внутрішньої організації університету. Йшлося про поділ на факультети, причому кожен факультет наділявся повноваженнями «встановлювати статути й порядки, які виявляться потрібними щодо способу й годин читання, щодо диспутації, костюма, поховання померлих, щодо бакалаврів, таксування квартир, дисциплінарних заходів щодо неслухняних» [14, с. 35].

Втручання Людовика IX в життя Паризького університету відбулося ще тоді, коли він навіть не мав усієї повноти влади, але заради магістрів і студентів пішов проти волі своєї владолюбної матері королеви Бланки Кастильської - регента королівства. Коли 1257 року в університеті розгорівся конфлікт між магістрами - представниками білого духовенства і викладачами богословського факультету, ченцями домініканського та францисканського орденів, король для наведення порядку у стінах університету відправив у вигнання Гійома Де Сент-Амура - авторитетного серед студентів і магістрів богослова.

Людовик IX для поліпшення функціонування університету став співзасновником (спільно 3 Робером де Сорбоном) коледжу для бідних магістрів-теологів. Незважаючи на те, що Людовик IX усе своє правління уявляв як утвердження ідеалу християнського правителя, під час виконання своєї місії він знайшов час і сили для удосконалення осередків культури й освіти.

Висновки. Загалом особистість державців епохи Високого Середньовіччя повністю виразилася в діяннях у царині духовного життя. Імператора Фрідріха II дослідники часто вважають особистістю, яка значно випередила свій час. Фактично, це правитель епохи Ренесансу - державець макіавеллістського типу. Ренесансною також була його славнозвісна «допитливість», прагнення дізнатися і збагнути якомога більше зі світової культурної спадщини - ренесансний універсалізм. Звідси і його небачена для Західної Європи того часу релігійна толерантність. Не тільки прагненням надати особливого блиску своєму дворові пояснюється утримання й опіка 
видатних інтелектуалів епохи у столиці Сицилійського королівства Палермо.

Імператор дійсно кохався в поезії, філософії, науці як справжній ренесансний монарх. Однак це був надзвичайно проникливий, далекоглядний і холодно-жорстокий політик і полководець. Інтерес до наукових знань, мистецтва та літератури ніколи не відволікав Фрідріха II від головного - утримання влади, іiі зміцнення й піднесення імперії над папством. Неаполітанський університет став першим світським вищим навчальним закладом європейського середньовіччя.

Засновуючи університет, Фрідріх II насамперед дбав про створення правлячої верстви в Сицилійському королівстві, а можливо, й у всій імперії, населення якої було б не тільки освіченим, але й особисто відданим імператорові. Тому в навчальному процесі запроваджувалися курси, які були позбавлені церковної схоластики як засобу залежності від папського престолу. Поряд із цим викладання юриспруденції в Неаполі уникло впливу правових ідей Болонського університету. Адже політична свобода ломбардських міст визначала характер викладання права у Болоньї, чого не можна було допустити в імператорському університеті. Неаполітанська вища школа перебувала під дріб'язковим контролем імперської влади.

Світський навчальний заклад не працював на секуляризацію суспільної свідомості й ніяким чином не утверджував гуманістичні ідеї. Неаполітанський університет за Фрідріха II працював на його державу, забезпечуючи якісне функціонування державного механізму, створюючи умови для піднесення Сицилійського королівства і зростання величі Священної Римської імперії. Е. Канторович у своїй книзі про Фрідріха II наголошував, що він був першим імператором, який цілеспрямовано й умисно спробував встановити свою верховну владу й над свідомістю своїх підданих $[10$, с. 135]. Власне, саме ця обставина й зумовила особливий феномен: не тільки в роки правління імператора і його найближчих наступників, але й до кінця Середніх віків Неаполітанський університет не дав світові випускників рівня П'єра Абеляра чи Альберта Великого. Приклад винятково утилітарного підходу до університетської справи ще в епоху Високого Середньовіччя показує сучасним реформаторам від освіти, що великих проривів у філософії і науці він не забезпечує.

Ставлення Людовика IX до Паризького університету визначалося його розумінням своєї місії благочестивого монарха християнської держави. Король із ранніх літ сприйняв панівну в епоху Високого Середньовіччя концепцію "translatio studii", зміст якої був своєрідним відображенням концепції «трансляції імперії» (від царств Давнього Сходу до Римської імперії, а від неї до Священної Римської імперії Середніх віків). "Translatio studii" означало, що поряд із переходом влади до Священної Римської імперії відбувається й перехід інтелектуальної влади з Афін до Рима, а від Рима - до Парижа. Освічені європейці епохи Високого Середньовіччя уявляли Рим політичною столицею, а Париж завдяки університету - інтелектуальною столицею християнського світу. Тому страйк паризьких магістрів і студентів 1229-1231 pp. реально загрожував втратою столицею Французького королівства свого інтелектуального блиску. Юний король, збагнувши це, негайно вжив заходів для збереження університету у своїй столиці.

На відміну від імператора, французький король протягом свого правління залишався осторонь активного інтелектуального життя Паризького університету. Його мало цікавили абстрактні й відірвані від повсякденного життя благочестивого християнина богословські і філософські дискуciï. Завдяки цьому тут виникла атмосфера вільного наукового дискурсу. Теологічний факультет у Парижі став центром європейської середньовічної схоластики. Людовик IX у стосунках із Паризьким університетом обрав позицію мудрого опікуна і благодійника без претендування на статус видатного інтелектуала. Така позиція французького короля виявилася більш корисною для університету в перспективі, ніж позиція імператора щодо свого університету в Неаполі - позиція власника, наставника і наглядача.

\section{Список літератури:}

1. Абрамсон М.Л. Фридрих II Сицилийский и его епоха. Средневековая Европа глазами современников и историков. Книга для чтения. Часть II. Европейский мир $X-X V$ вв. Серия «Всемирная история и культура глазами современников и историков». Москва : Интерпракс, 1995. С. 257-291.

2. Бруно Глогер. Император, бог и дьявол: Фридрих II Гогенштауфен в истории и сказаниях. Москва : Евразия, 2003. 288 с.

3. Вальтер фон дер Фогельвейде. Стихотворения. Москва : «Наука», 1985. 386 с.

4. Вис Э.В. Фридрих II Гогенштауфен. Москва : АСТ: Транзиткнига, 2005. 378 с. 
5. Воскобойников О.С. Гости в культурной жизни двора Фридриха II. Двор монарха в средневековой Европе: явление, модель, среда / Под редакиией Н.А. Хачатурян. Вып. I. Москва; Санкт-Петербург : Алетейя, 2001. С. 245-260.

6. Воскобойников О.С. Достоинства целебных источников на Флегрейских полях, или Культура тела при дворе Фридриха II. Священное тело короля: ритуаль и мифология власти / [отв. ред. Н.А. Хачатурян]; Ин-т всеобщ. Истории РАН; МГУ им. М.В. Ломоносова. Москва : Наука, 2006. С. 293-344.

7. Жан де Нострдам. Жизнеописания древнейших и наиславнейших провансальских пиитов, во времена графов Прованских процветших. Москва : Наука, 1993. 740 с.

8. Жуанвиль Жан де. Книга благочестивых речений и добрых деяний нашего святого короля Людовика. Санкт-Петербург : Евразия, 2012. 400 с.

9. Казанский И. Средневековая лирика. Книга для чтения по истории средних веков / Под ред. П.Г. Виноградова. Выпуск второй. Москва : Товарищество типографий А.И. Мамонтова, 1897. С. 820-830.

10. Kantorovich E. Frederick the Second (1194-1250). FREDERICK UNGAR PUBLISHING CO. NEWYORK, 1964. $761 \mathrm{p}$.

11. Ле Гофф Ж. Людовик IX Святой. Москва : Ладомир, 2001. 800 с.

12. Люшер А. Французское общество времен Филиппа Августа. Санкт-Петербург : Евразия, 1999. 414 с.

13. Мари-Анн Поло де Болье. Средневековая Франция. Москва : Вече, 2014. 384 с.

14. Суворов Н.С. Средневековые университеты. Москва : Книжный дом «ЛИБРОКОМ», 2012. 256 с.

15. Шерр И. Германия. История цивилизации за 2000 лет: в 2-х т. Т. 1. Минск : МФЦП, 2005. 544 с.

\section{Hordiyenko V.V., Hordiyenko H.M. THE ROLE OF EDUCATION AND CULTURE IN THE MISSIONS OF FRIEDRICH II von HOHENSTAUFEN AND LOUIS IX, SAINT}

The article presents the comparative analysis of an important aspect of outstanding monarchs' reform activities in the period of the High Middle Ages in Western Europe - emperor of the Holy Roman Empire Friedrich II von Hohenstaufen and king of France Louis IX Saint. The paper characterizes emperor's and king's interests to the development of literature art education and culture. We reveal the motives for monarch's close communication with outstanding intellectuals of the High Medieval Period. The article singles out the peculiarities of Friedrich II's and Louis IX's contacts with poets, artists and theologians. The paper presents the analysis of rulers' attitudes towards troubadours', trouvers' and minstrels 'poetic creativity.

It is pointed out that Friedrich II contributed to the beginnings of "Sicilian School of Poets" which had a significant influence on European literature development. We claim that the emperor's court consisted of not only poets and artists but also thinkers, and scientists known in that period. We highlight that French king Louis IX was not fond of chivalry poetry although he did not prohibit it in his kingdom. He was fascinated with clerical artistic petit genres: sermon, clerical music, book miniature. Louis IX in contrast to Friedrich II communicated and cooperated more with intellectuals of the middle level, namely, Robert Sorbo and Vincent de Beauvais.

We expose the monarchs'ideas about the phenomenon of medieval university and its mission. It is highlighted that it was Friedrich II who broke pope's monopoly on the foundation of universities opening the first secular higher educational establishment in Middle Ages in Naples. Although Louis IX did not directly relate to the foundation of the University of Paris, he did everything possible for masters and students to return to Paris after the strike of 1229-1231. We draw the conclusion that Louis IX' mission as the tolerant curator and contributor of the University of Paris was much more beneficial and productive than Friedrich II's totalitarian and pragmatic approach to the university in Naples.

Key words: Friedrich II, Louis IX, the University of Naples, the University of Paris, intellectuals, education. 